Website: http://journal.umy.ac.id/index.php/mrs

DOI: $10.18196 / \mathrm{jmmr} .5108$.

\title{
Kepuasan dan Motivasi Tenaga Medis : Studi Kasus Terhadap Pendapatan, Kompensasi dan Lingkungan Kerja Pada Rumah Sakit Umum Daerah Dr. Soedirman Kabupaten Kebumen
}

\author{
Iwan Danardono $^{1^{*}}$ \& Firman Pribadi ${ }^{2}$ \\ *Penulis Korespondensi: iwan_danardono@yahoo.com \\ ${ }^{1}$ Rumah Sakit Umum Daerah Dr. Soedirman Kabupaten Kebumen \\ ${ }^{2}$ Magister Manajemen Rumah Sakit Universitas Muhammadiyah Yogyakarta \\ INDEXING \\ Keywords: \\ Job satisfaction, \\ motivation, \\ remuneration, working \\ conditions

\begin{abstract}
A B S T R A C T
The purpose of this study was to examinee the relationship between health worker incomes and work environment to their satisfactionand motivation. This study descriptive qualitative case study design with objects are medical staff. Questionare based on Impact Toolkit "Health Worker Incentives Survey (HWIS)"from University of Abeerden. The amount of revenue sand services received fluctuate and differ from individual to individual. There is a disparity between medical personnel and civil servants PTT, and between types of medical personnel in terms of the amount of revenue and services received, it causes the majority of respondents have low incomes choose the level of job satisfaction at the level of medium and low, but caused no desire to move the workplace. there are respondents who complained of poor working conditions and this led to their job satisfaction in the low category.
\end{abstract}

Tujuan penelitian ini mengetahui hubungan pendapatan, tunjangan, dan kondisi kerja terhadap Kepuasan Dan Motivasi Tenaga Medis. Penelitian ini merupakan penelitian deskriptif kualitatif dengan rancangan studi kasus yang dilakukan di RSUD dr. Soedirman Kebumen dengan obyek penelitian seluruh tenaga medis. Kuesioner menggunakan Immpact Toolkit "Health Worker Incentives Survey (HWIS)" dari Universitas Abeerden. Terdapat disparitas yang cukup besar antara tenaga medis PNS dan PTT, dan antar jenis tenaga medis dalam hal besaran pendapatan dan jasa pelayanan yang diterima, hal menyebabkan sebagian besar responden yang memiliki pendapatan rendah memilih tingkat kepuasan kerja pada level sedang dan rendah, namun tidak menimbulkan keinginan berpindah tempat pekerjaan. Sedangkan kondisi lingkungan kerja sebagian besar responden menyatakan bagus, namun masih terdapat responden yang mengeluhkan kondisi kerja yang jelek dan hal ini menyebabkan kepuasan kerja mereka dalam kategori rendah.

(C) 2016 JMMR. All rights reserved

\section{PENDAHULUAN}

Rumah sakit bertugas untuk selalu memberikan pelayanan yang sesuai dengan kebutuhan dan keinginan pasien. Pelayanan yang diberikan harus bermutu lebih baik, penanganan pasien lebih cepat, harga relatif murah dan bermanfaat. Oleh karena itu, tidak dapat dipungkiri bahwa, dalam pengelolaan rumah sakit, kinerja sumber daya sangat dibutuhkan untuk mencapai tujuan organisasi rumah sakit.

Sumber daya manusia merupakan sumber daya yang memiliki banyak kelebihan dibanding sumber daya lain yang ada pada organisasi. Kelebihan tersebut menjadi sebuah potensi yang positif. Potensi- potensi yang dimiliki sumber daya manusia mempengaruhi organisasi dalam mencapai tujuannya. Manajer dituntut mampu menimbulkan motivasi karyawan, dimana motivasi berhubungan erat dengan keberhasilan organisasi di dalam mencapai tujuantujuannya.

Menurut Uno (2006), motivasi adalah dorongan dasar yang menggerakkan seseorang bertingkah laku. Dorongan ini berada pada diri seseorang yang menggerakkan untuk melakukan sesuatu yang sesuai dengan dorongan dalam dirinya. ${ }^{1}$ Menurut Gomes (2003), motivasi seorang pekerja merupakan hal yang rumit, karena melibatkan faktor-faktor individual dan faktor-faktor organisasional. Yang bersifat individual 
adalah kebutuhan-kebutuhan (needs), tujuan-tujuan (goals), sikap (attitudes), dan kemampuan (abilities), sedangkan yang bersifat organisasional adalah pembayaran atau gaji (pay), keamanan pekerjaan (job security), sesama karyawan (co workers), - pengawasan (supervision), pujian (praise) dan pekerjaan itu sendiri (job it self). ${ }^{2}$

Menurut Gomes (2006) tugas manajemen sumber daya manusia berkaitan dengan upaya mengelola unsur manusia dengan segala potensi yang dimilikinya harus dilakukan seefektif mungkin sehingga dapat diperoleh sumber daya manusia yang puas (satisfied) dan memuaskan (satisfactory) bagi organisasi. ${ }^{3}$

Kepuasan kerja adalah keadaan emosional yang menyenangkan atau tidak menyenangkan dimana karyawan memandang pekerjaannya. Kepuasan kerja merupakan cerminan perasaan karyawan terhadap pekerjaannya. Karyawan yang merasa puas, maka akan timbul sikap positif terhadap pekerjaan dan lingkungannya. Menurut Martoyo (2007), kompensasi adalah pengaturan keseluruhan pemberian balas jasa bagi "employers" maupun "employees" baik yang langsung berupa uang (finansial) maupun yang tidak langsung berupa non uang (non finansial). ${ }^{4}$

Menurut Bestari (2005) macam-macam kompensasi yang diberikan pada karyawan meliputi : (a) Kompensasi financia langsung, yakni kompensasi berupa uang bayaran (pay) yang diterima oleh seseorang dalam bentuk gaji, upah, bonus uang, dan komisi. (b) Kompensasi financial tidak langsung. Kompensasi ini disebut juga dengan tunjangan yang meliputi semua imbalan berupa uang namun tidak diberikan secara langsung seperti tunjangan hari tua/ pensiun, tunjangan asuransi kesehatan, tunjangan pendidikan, dan tunjangan lainnya. (c) Kompensasi non Financial . Merupakan kompensasi yang tidak selalu dapat diuangkan, seperti penghargaan, pujian, maupun kepuasan yang diperoleh seseorang dari pekerjaan itu sendiri atau dari lingkungan psikologis dan atu fisik dimana orang tersebut bekerja. ${ }^{5}$

Menurut mathis dan Jackson (2006) kompensasi merupakan faktor penting yang mempengaruhi bagaimana dan mengapa orang-orang yang memilih untuk bekerja disebuah organisasi dari pada organisasi yang lain. Dalam perjalanannya, kompensasi lebih dikenal pada masa sekarang dengan istilah remunerasi. ${ }^{6}$ Sistem remunerasi merupakan sistem distribusi pembagian hak karyawan atas pelaksanaan Job Description masing-masing karyawan. Remunerasi tidak hanya mengatur tentang insentif tetapi lebih komprehensif yaitu mengatur bagaimana penghargaan yang menjadi hak karyawan dapat diterimanya secara benar melalui proses yang logis, transparan dan akuntabel.

Upaya peningkatan produktivitas kerja perlu memperhatikan lingkungan kerja. Keberhasilan organisasi dalam mewujudkan tujuan tergantung pada lingkungan kerja dalam organisasi tersebut. Nitisemito (2002) mengatakan bahwa Lingkungan kerja adalah segala sesuatu yang ada disekitar para pegawai yang dapat mempengaruhi dirinya dalam menjalankan tugas-tugas yang diembannya. ${ }^{7}$

Menurut Robbins (2002) Lingkungan kerja fisik juga merupakan faktor penyebab stress kerja pegawai yang berpengaruh pada prestasi kerja. Faktor-faktor yang mempengaruhi lingkungan kerja fisik adalah: suhu, kebisingan, penerangan, mutu udara. ${ }^{8}$

Jadi terdapat beberapa faktor yang mempengaruhi kinerja tenaga medis yaitu antara lain kepuasan dan motivasi kerja, sementara itu faktor yang mempengaruhi kepuasan dan motivasi kerja dokter adalah kompensasi dan lingkungan kerja. Rumusan masalah pada penelitian ini yang pertama adalah bagaimana pendapatan dan tunjangan dalam sistem kompensasi/remunerasi yang dijalankan di RSUD Dr. Soedirman Kabupaten Kebumen, yang kedua bagaimana kondisi lingkungan kerja yang ada di RSUD Dr. Soedirman Kabupaten Kebumen dan rumusan ketiga adalah bagaimana hubungan pendapatan, tunjangan dan lingkungan kerja terhadap kepuasan dan motivasi kerja di RSUD dr. Soedirman Kabupaten Kebumen untuk kalangan tenaga medis. Tujuan penelitian ini adalahUntuk mengetahui hubungan pendapatan, tunjangan (kompensasi/ remunerasi) dan lingkungan kerja terhadap kepuasan dan motivasi kerja RSUD Dr. Soedirman Kabupaten Kebumen untuk kalangan tenaga medis.

\section{METODE PENELITIAN}

\section{Profil RSUD dr. Soedirman Kebumen}

RSUD dr. Soedirman merupakan SKPD yang menerapkan Pola Pengelolaan Keuangan Badan Layanan Umum Daerah. Memiliki tempat tidur sebanyak 198 dan 553 karyawan. 


\section{Karakteristik Responden}

\section{Jenis kelamin}

Hasil analisis deskriptif karakteristik responden berdasarkan jenis kelamin diketahui sebagian besar responden berjenis kelamin laki-laki (61\%).

\section{Pendidikan}

Karakteristik responden menurut pendidikan diketahui mayoritas adalah dokter spesialis (64\%).

\section{Status pernikahan}

Hasil analisis deskriptif responden diketahui 92\% berstatus menikah dan $8 \%$ belum menikah.

\section{Pendapatan dan insentif}

Sumber pendapatan tenaga medis berasal dari gaji sebagai pegawai dan insentif atau jasa pelayanan. Gaji tetap terbesar adalah dokter spesialis dan gaji tetap terkecil dari dokter umum dan dokter gigi PTT. Sedangkan insentif terbesar diterima oleh dokter spesialis penyakit dalam, dan terendah dari golongan dokter gigi. Besaran gaji dan insentif disajikan pada tabel 3 dan table 4 .

\section{Tunjangan-tunjangan}

Hasil analisis deskriptif yang berkaitan dengan tunjangan baik pendidikan dan tunjangan lain bagi tenaga medis tersaji pada tabel 5 dan tabel 6 .

\section{Kondisi kerja}

Hasil analisis dekskriptif kondisi kerja, diketahui $57 \%$ responden menyatakan kondisi bagus, $28 \%$ menyatakan kondisi sedan dan 15\% menyatakan kondisi jelek. Hasil di sajikan pada tabel 7.

\section{Kepuasan kerja}

Hasil analisis deskriptif kepuasan kerja diketahui $62 \%$ menyatakan kepuasan kerja pada level tinggi, $27 \%$ pada level sedang dan $11 \%$ pada level rendah. Hasil disajikan pada tabel 8 .

\section{Motivasi kerja}

Kuesioner tentang motivasi adanya keinginan untuk pindah ke RS lain, dari 39 responden, 85\% menyatakan tidak ada keinginan untuk pindah, dan $15 \%$ menyatakan ragu-ragu. Hasil disajikan pada tabel 10 .

\section{HASIL DAN PEMBAHASAN}

Tabel 3. Deskripsi gaji tetap tenaga medis di RSUD dr. Soedirman

\begin{tabular}{|c|c|c|c|}
\hline NO & Penerima & Jumlah Gaji & Keterangan \\
\hline 1 & dr. Umum \& dr. Gigi PNS & 3.500 .000 & $\begin{array}{l}\text { Jumlah gaji terendah, naik berjenjang sesuai } \\
\text { lama kerja dan golongan }\end{array}$ \\
\hline 2 & dr. Umum \& dr. Gigi PTT & 1.250 .000 & Tidak ada kenaikan jenjang \\
\hline 3 & Dr. Spesialis PNS & 3.700 .000 & $\begin{array}{l}\text { Jumlah gaji terendah, naik berjenjang sesuai } \\
\text { lama kerja dan golongan }\end{array}$ \\
\hline 4 & Dr. Spesialis PTT & 2.000 .000 & Tidak ada kenaikan jenjang \\
\hline
\end{tabular}


Tabel.4. Penerimaan Jasa Pelayanan/ Insentif bulan Januari-Maret 2015.

\begin{tabular}{|c|c|c|c|c|c|c|}
\hline NO & Penerima & Januari & Februari & Maret & $\begin{array}{c}\text { Rata-Rata/ } \\
\text { bulan }\end{array}$ & Ket-erangan \\
\hline 1 & Sp. Dalam 1 & 57.317 .390 & 71.051 .807 & 95.941 .811 & 74.770 .336 & Tertinggi \\
\hline 2 & Sp. Dalam 2 & 33.746 .235 & 32.549 .589 & 46.472 .502 & 37.589 .442 & \\
\hline 3 & Sp. Dalam 3 & 19.370 .056 & 28.721 .689 & 44.250 .825 & 30.780 .857 & \\
\hline 4 & Sp. Bedah 1 & 20.624 .666 & 24.996 .014 & 41.516 .570 & 29.045 .750 & \\
\hline 5 & Sp. Bedah 2 & 17.125 .456 & 27.455 .852 & 38.285 .143 & 27.622 .150 & \\
\hline 6 & Sp. Obsgyn 1 & 33.202 .636 & 20.464 .946 & 31.082 .321 & 28.249 .968 & \\
\hline 7 & Sp. Obsgyn 2 & 27.861 .537 & 22.105 .174 & 29.741 .535 & 26.569 .415 & \\
\hline 8 & Sp. Obsgyn 3 & 21.998 .639 & 37.823 .622 & 50.481 .358 & 36.767 .873 & \\
\hline 9 & Sp. Anak 1 & 23.828 .025 & 25.838 .538 & 31.246 .018 & 26.970 .860 & \\
\hline 10 & Sp. Anak 2 & 28.004 .590 & 22.068 .576 & 49.495 .893 & 33.189 .686 & \\
\hline 11 & Sp. Syaraf 1 & 11.906 .212 & 23.605 .050 & 25.857 .852 & 20.456 .371 & \\
\hline 12 & Sp. Syaraf 2 & 6.696 .613 & 18.630 .427 & 12.460 .404 & 12.595 .815 & \\
\hline 13 & Sp. Paru & 13.196 .570 & 17.769 .897 & 30.551 .786 & 20.506 .084 & \\
\hline 14 & Sp. Kulit & 4.035 .967 & 6.390 .587 & 7.952 .015 & 6.126 .190 & \\
\hline 15 & Sp. Radiologi 1 & 9.773 .941 & 9.835 .500 & 12.969 .479 & 10.859 .640 & \\
\hline 16 & Sp. Radiologi 2 & 7.015 .788 & 11.039 .394 & 10.070 .684 & 9.375 .289 & \\
\hline 17 & Sp. Patologi 1 & 22.966 .626 & 18.935 .591 & 30.916 .204 & 24.272 .807 & \\
\hline 18 & Sp. Patologi 2 & 2.607 .470 & 13.770 .659 & 26.874 .868 & 21.626 .499 & $\begin{array}{l}\text { efektif } 2 \\
\text { bulan }\end{array}$ \\
\hline 19 & Sp. Anasthesi 1 & 15.913 .991 & 15.862 .384 & 22.176 .824 & 17.984 .399 & \\
\hline 20 & Sp. Anasthesi 2 & 22.562 .251 & 29.638 .839 & 47.821 .220 & 33.340 .770 & \\
\hline 21 & Sp. Gigi & 997.262 & 1.500 .744 & 1.781 .730 & 1.426 .579 & \\
\hline 22 & Sp. THT & 10.472 .974 & 12.543 .080 & 17.915 .463 & 13.643 .839 & \\
\hline 23 & Sp. Mata & 24.187 .316 & 25.085 .600 & 55.554 .390 & 34.942 .435 & \\
\hline 24 & Sp. Jantung & 960.575 & 1.936 .013 & 12.872 .874 & 5.256 .487 & \\
\hline 25 & Sp. Orthopedi & & & 23.743 .564 & 23.743 .564 & $\begin{array}{l}\text { efektif } 1 \\
\text { bulan }\end{array}$ \\
\hline 26 & Dokter Umum & 3.544 .550 & 3.890 .117 & 6.430 .425 & 4.621 .697 & $\begin{array}{l}\text { rata-rata/ } \\
\text { orang }\end{array}$ \\
\hline 27 & Dokter Gigi & 912.338 & 1.590 .194 & 1.653 .044 & 1.385 .192 & Terendah \\
\hline
\end{tabular}


Tabel 5. Pemberian Tunjangan Pelatihan bagi tenaga medis

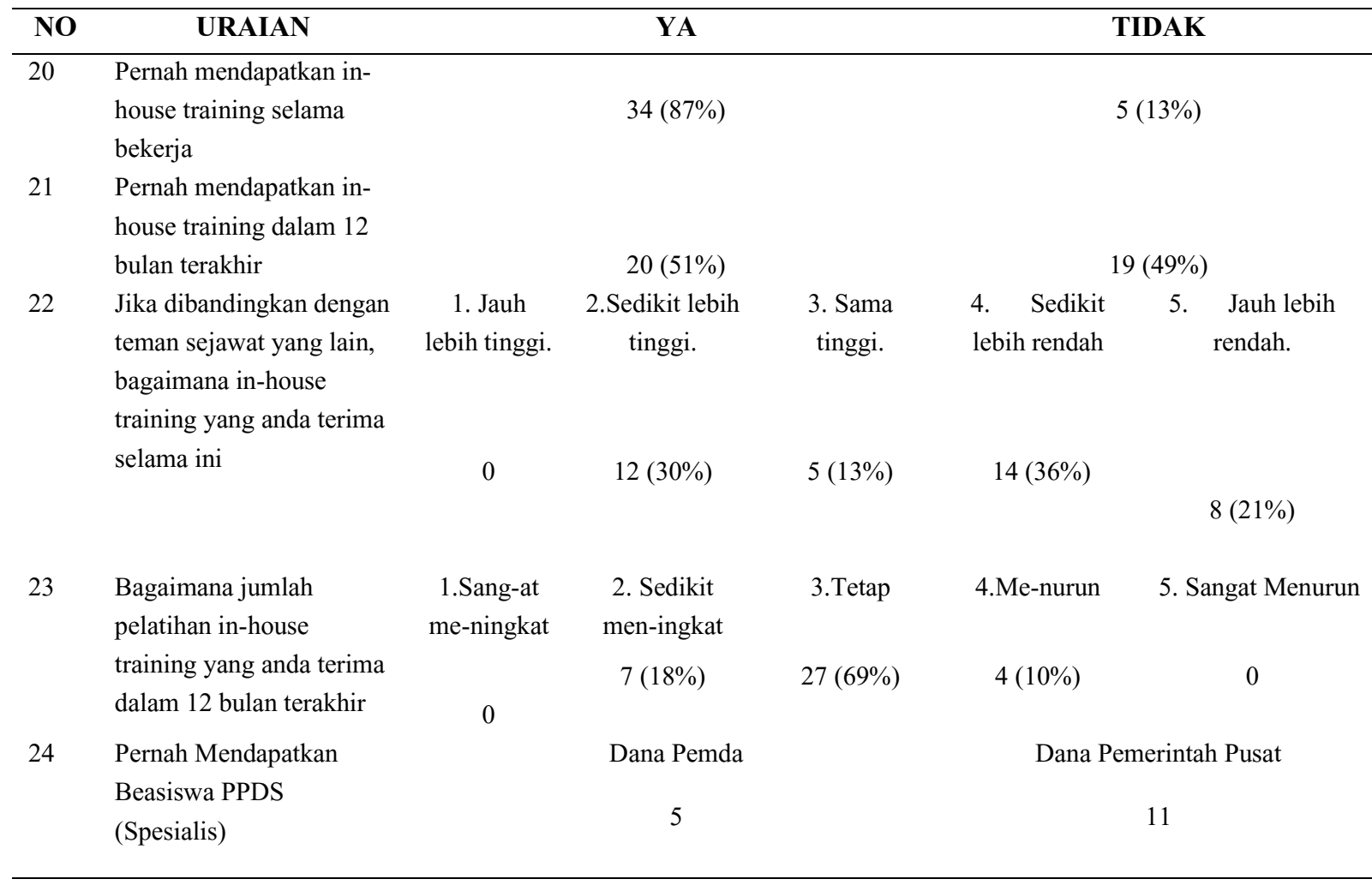

Tabel 6. Tunjangan Lain yang diterima oleh Tenaga Medis

\begin{tabular}{|c|c|c|c|c|}
\hline & Uraian & Ya & Tidak & Ragu-ragu \\
\hline a. & Tunjangan daerah terpencil & & $39(100 \%)$ & \\
\hline b. & Tunjangan rumah/rumah dinas & $7(18 \%)$ & $8(20 \%)$ & $24(62 \%)$ \\
\hline c. & Tunjangan akomodasi & & $39(100 \%)$ & \\
\hline d. & Tunjangan transportasi & $2(5 \%)$ & $37(95 \%)$ & \\
\hline e. & Tunjangan kesehatan & $30(77 \%)$ & $9(23 \%)$ & \\
\hline f. & Tunjangan pensiun & $3077(\%)$ & $9(23 \%)$ & \\
\hline g. & Tunjangan lembur & & $39(100 \%)$ & \\
\hline h. & Tunjangan seragam & $39(100 \%)$ & & \\
\hline i. & Tunjangan resiko & $2(5 \%)$ & $37(95 \%)$ & \\
\hline j. & Tunjangan non praktek & & $39(100 \%)$ & \\
\hline
\end{tabular}


Tabel 7. Analisis deskriptif kondisi kerja

\begin{tabular}{lccccc}
\hline \multicolumn{1}{c}{47} & $\begin{array}{c}\text { 1.Sangat } \\
\text { bagus }\end{array}$ & 2.Bagus & 3.Sedang & 4.Jelek & $\begin{array}{c}\text { 5.Sangat } \\
\text { jelek }\end{array}$ \\
\hline $\begin{array}{l}\text { Bagaimana } \\
\text { anda } \\
\text { menjelaskan } \\
\text { gedung } \\
\text { tempat } \\
\text { bekerja } \\
\text { anda }\end{array}$ & 0 & 22 & 11 & 6 & 0 \\
$\%$ & $0 \%$ & $57 \%$ & $28 \%$ & $15 \%$ & $0 \%$ \\
\hline
\end{tabular}

Tabel 8. Analisis deskriptif Kepuasan kerja

\begin{tabular}{|c|c|c|c|c|c|}
\hline Uraian & 1.Sangat tinggi & 2. Tinggi & 3.Sedang & 4.Rendah & $\begin{array}{c}\text { 5.Sangat } \\
\text { rendah }\end{array}$ \\
\hline $\begin{array}{l}\text { Bagaimana anda } \\
\text { menjelaskan } \\
\text { tingkat kepuasan } \\
\text { dengan } \\
\text { pekerjaan anda }\end{array}$ & 0 & 24 & 11 & 4 & \\
\hline$\%$ & 0 & $62 \%$ & $27 \%$ & $11 \%$ & 0 \\
\hline
\end{tabular}

Tabel 9. Persepsi responden terhadap tingkat remunerasi

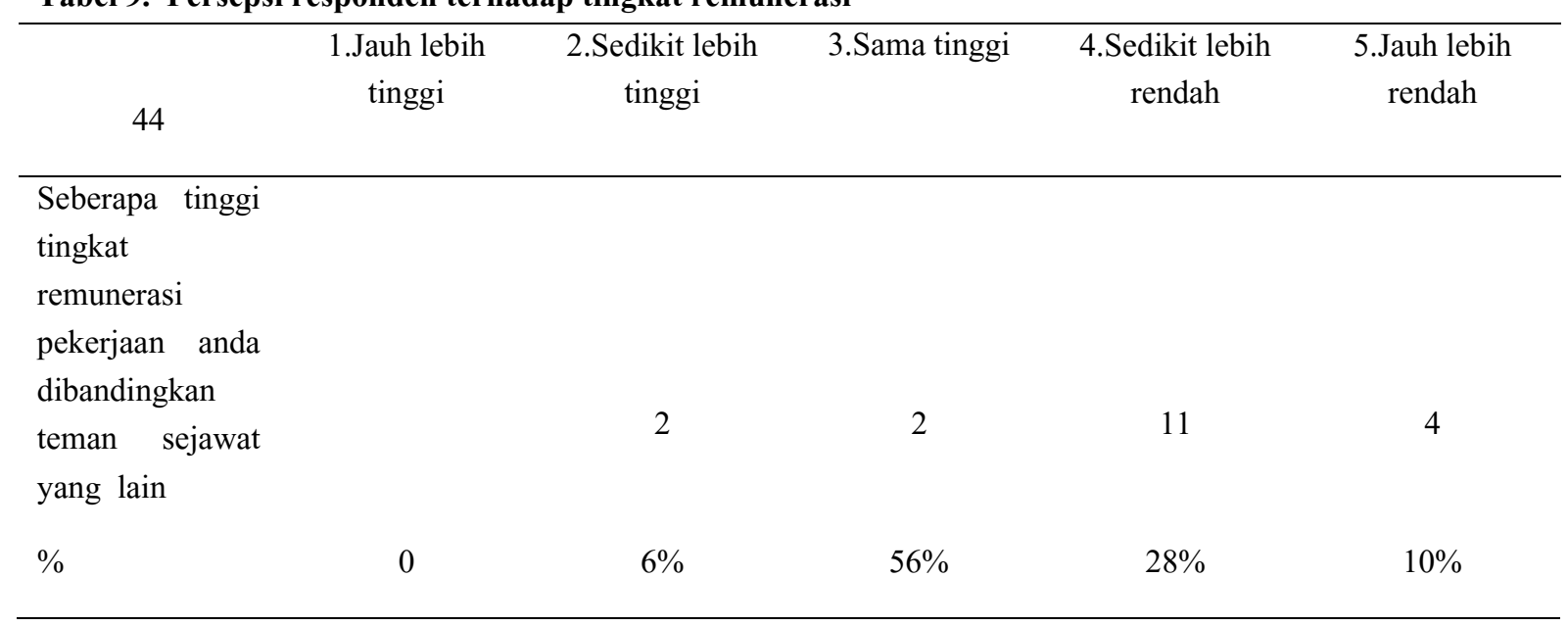


Tabel 10. Analisis deskriptif motivasi kerja

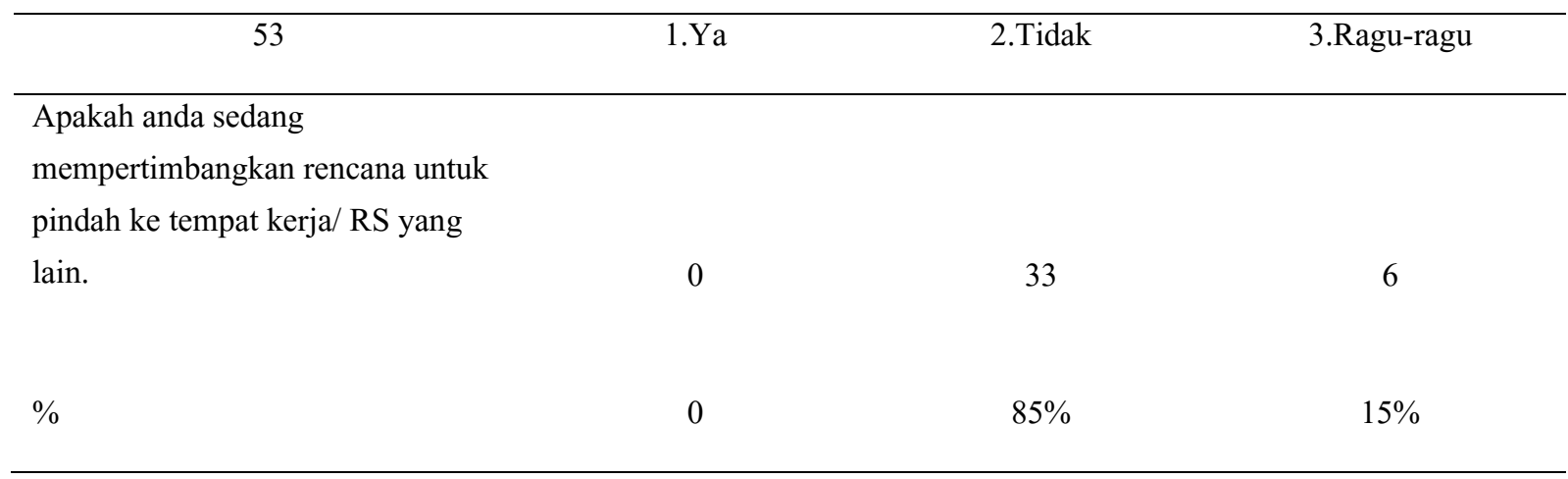

\section{Pembahasan}

\section{Implementasi kompensasi finansial}

Pendapatan Tenaga Medis di RSUD dr. Soedirman Kabupaten Kebumen berupa Gaji pokok dan tunjangan-tunjangan yang diterima oleh masingmasing tenaga medis setiap bulannya. Sedangkan Kompensasi berupa insentif/ Jasa Pelayanan yang dibayarkan secara bulanan atas jasa/ tindakan yang dilaksanakan dalam memberikan pelayanan kepada pasien. Gaji pokok Tenaga Medis PNS berasal dari dana APBN yang diterima daerah dalam bentuk Dana Alokasi Umum, dan dibayarkan sesuai peraturan yang berlaku sesuai jenjang kepangkatan. Sedangkan untuk Tenaga Medis Non PNS maupun dokter tamu, diberikan gaji yang bersumber dari belanja operasional dan besarnya diatur dengan Peraturan Direktur rumah sakit. Gaji tersebut tidak lebih besar dari gaji tenaga medis PNS karena tidak ada tunjangan-tunjangan. Hal ini juga rawan menyebabkan terjadinya kecemburuan karena antara tenaga medis PNS maupun yang non PNS beberapa diantaranya bertugas ditempat yang sama dengan beban kerja yang tidak jauh berbeda.

Jasa pelayanan/ insentif adalah imbalan yang diterima oleh semua komponen yang dalam rangka observasi, diagnosis, pengobatan, konsultasi, visite/pengawasan medis, dan / atau pelayanan lainnya yang diberikan oleh tenaga medis, tenaga non medis, dan semua komponen yang terlibat dalam mendukung pelayanan kesehatan di RSUD. Diperoleh gambaran bahwa sebaran insentif antar jenis tenaga medis cukup beragam dengan range yang cukup lebar antara yang paling besar hingga paling rendah. Jasa medis yang besar didominasi oleh 4 spesialis utama, sedangkan yang terendahmerupakan jasa yang diterima dokter gigi dan dokter umum. Dengan melakukan cross sectional hasil wawancara, hal ini menyebabkan ketidakpuasan. . Namun diharapkan ada solusi untuk mengurangi disparitas tersebut dengan pemberian tunjangan yang bersifat tetap agar dokter spesialis tertentu yang tidak populer atau dokter umum dan dokter gigi tetap memiliki kompensasi yang sebanding dengan kebutuhan rumah sakit untuk menyediakan pelayanan yang lengkap.

\section{Implementasi kompensasi non finansial}

\section{Tunjangan pendidikan}

Sebanyak tiga puluh empat responden (87\%) menyatakan pernah memperoleh pelatihan terkait bidang tugasnya, kecuali dokter tidak tetap yang kurang dari 2 tahun bekerja sebanyak lima responden (13\%). Terdapat kesepakatan tidak tertulis bahwa setiap Satuan Medis Fungsional berhak mendapatkan pelatihan setiap dua tahun satu kali. Namun pemberian pelatihan tersebut tidak diberikan secara reguler, karena disesuaikan ketersediaan anggaran dan ada atau tidaknya kegiatan dari penyelenggara pelatihan. Untuk dokter spesialis mendapatkan porsi lebih sering dalam mengikuti pelatihan, sedangkan untuk dokter umum jarang. Untuk biaya/ tunjangan mengikuti pelatihan sendiri terdapat kebijakan dilakukan sharing atau iur biaya antara pihak rumah sakit dengan tenaga medis yang mengikuti.

\section{Tunjangan perumahan, transportasi, kesehatan dan lainnya}

Pemberian tunjangan merupakan mekanisme sebagai kompensasi untuk menutup permasalahan 
kesenjangan yang diakibatkan perbedaan status kepegawaian dan sistem pengajian.Tunjangan berupa pemberian jasa pelayanan/ insentif sebagaimana dijelaskan sebelumnya hanyalah kompensasi atas pelayanan yang diberikan, namun tidak mencerminkan adanya upaya mempersempit kesenjangan.

RSUD dr. Soedirman memiliki beberapa rumah dinas yang ditempati dokter maupun tenaga paramedis. Karena jumlahnya terbatas sehingga hanya sedikit yang dapat menikmati rumah dinas tersebut, yakni hanya 7 tenaga medis (18\%). Sedangkan untuk tunjangan perumahan dalam bentuk uang/ kompensasi 24 responden (61\%) menyatakan tidak menerima, namun jawaban tersebut lebih karena ketidaktahuan responden akan adanya tabungan perumahan/ Taperum. Bagi dokter PNS mendapatkan tunjangan berupa penyertaan dana pemerintah dalam bentuk tabungan perumahan yang jumlahnya terbatas, yang hanya diberikan satu kali selama bekerja sebagai PNS, itupun besarannya hanya sebagai bantuan uang muka perumahan, dan dapat diuangkan hanya apabila yang bersangkutan pensiun dan tabungan tersebut belum diambil.

Tunjangan kesehatan bagi dokter PNS beserta keluarganya sudah melekat di gaji berupa iuran pemerintah kepada BPJS selaku pengelola dana kesehatan. Tunjangan ini memang tidak diterima secara langsung oleh PNS, namun PNS mendapat keringanan berupa sharing iuran BPJS dimana peserta BPJS Sosial (PNS) wajib membayar iuran sebesar $4 \%$ dari gaji pokok, negara menanggung iuran $3 \%$ dan PNS bersangkutan menanggung $1 \%$. PNS beserta keluarga yang tertanggung meliputi istri/ suami dan tiga orang anak dapat menikmatifasilitas kesehatan secara berjenjang sesuai kelasnya.

Tunjangan pensiun mirip dengan iuran BPJS, namun seluruhnya ditanggung oleh negara. Negara membayar iuran dana pensiun kepada PT. Taspen (Persero) selaku pengelola dana pensiun. PNS yang bersangkutan dapat menikmati dana pensiun tersebut setelah memasuki masa pensiun. Namun untuk dokter tamu dan dokter PTT tidak diberikan tunjangan kesehatan maupun tunjangan pensiun, dan memang belum ada kebijakan yang memayungi hal tersebut. Dalam wawancara diperoleh keterangan bahwa hal ini cukup membuat adanya perbedaan/gap dengan sesama teman sejawat, dan baik langsung atau tidak mempengaruhi persepsi terhadap kepuasan dalam bekerja.

\section{Kondisi lingkungann kerja}

Penelitian dilakukan setelah perpindahan dari gedung lama ke gedung baru selesai, sehingga jawaban responden merupakan informasi mengenai kondisi terkini, dan layak untuk dijadikan data penarikan kesimpulan dalam penelitian ini. $57 \%$ jawaban responden berpendapat bahwa gedung tempat bekerja saat ini bagus, $28 \%$ menyatakan sedang, dan $15 \%$ responden berpendapat bahwa gedung itu jelek. Responden yang berpendapat bahwa gedung yang baru jelek dapat dimaklumi karena memang beberapa sisi dan sarana gedung masih kurang baik, karena pembangunan yang sudah dimulai sejak lima tahun lalu, sehingga beberapa sisi yang sudah jadi lebih dulu menjadi tidak terawat. jauh lebih jelek apabila dibandingkan gedung tempat bekerja rekan sejawat mereka di RS lain.

Ketika diminta membandingkan dengan kondisi gedung rumah sakit lain di Kabupaten Kebumen, hanya $2 \%$ responden menyatakan kondisi gedung jauh lebih baik, $80 \%$ menyatakan kondisi gedung sedikit lebih baik, sedangkan $8 \%$ menyatakan sama baiknya, dan $10 \%$ menyatakan sedikit lebih jelek dari gedung rumah sakit lain. Sebagian besar responden yang menyatakan kondisi yang lebih baik dan lebih terstruktur di gedung baru dalam wawancara menyatakan hal tersebut meningkatkan motivasi mereka dalam bekerja, terutama daya dukung gedung dalam mempermudah pemberian pelayanan, peningkatan patient safety, dan mencegah kegagalan dalam pemberian pelayanan.

Hubungan pendapatan dan tunjangan dengan kepuasan dan motivasi. Tanggapan terhadap pernyataan kepuasan kerja menunjukkan bahwa $62 \%$ Responden menyatakan puas, walaupun tidak mencapai grade tertinggi. Dari hasil wawancara mereka menganggap pendapatan total meliputi gaji dan jasa pelayanan/ insentif sudah cukup memadai. Demikian halnya dengan kondisi gedung baru yang jauh lebih baik dari gedung lama cukup membuat responden termotivasi untuk bekerja. $27 \%$ respondenkurang puas dengan kondisi pekerjaan yang ada.Responden yang tidak puas sejumlah $11 \%$. Kondisi ini menyebabkan berkurangnya motivasi 
dalam melaksanakan tugas. Hal ini menunjukkan masih ada pekerjaan yang harus dibenahi oleh manajemen untuk mengurangi ketimpangan yang ada dalam hal penggajian dan pengurangan disparitaspendapatan antara jenis tenaga medis khususnya antara dokter spesialis dengan dokter umum dan dokter gigi.

Hubungan kondisi lingkungan kerja dengan kepuasan kerja 57\% menyatakan bahwa kondisi lingkungan tempat bekerja bagus dan sedikit lebih baik dari rumah sakit lain, dan setelah dilihat persepsi mereka terhadap kepuasan kerja mereka menyatakan memiliki kepuasan kerja tinggi. Sedangkan tiga dari empat responden adalah dokter gigi yang menyatakan tidak puas dalam pekerjaannya mengatakan bahwa kondisi lingkungan tempat bekerjanya jelek dan sedikit lebih jelek dari lingkungan kerja/ rumah sakit lain tempat rekan sejawatnya bekerja. Setelah dilakukan penelusuran melalui wawancara diperoleh keterangan bahwa kondisi lingkungan kerja mereka anggap jelek dikarenakan daya dukung peralatan kerja yang sangat minim. Peralatan merupakan peralatan lama yang tidak sebanding dengan kemajuan teknologi dan jumlah dokter, sehingga pelayanan harus antri antara satu dokter dengan dokter lain. Akibatnya dalam sehari satu dokter hanya bisa melayani 3-5 pasien saja.

\section{Angka drop out}

$88,6 \%$ responden menyatakan tidak tertarik untuk meninggalkan profesinya sekarang sebagai tenaga medis. $11,4 \%$ responden menyatakan ragu-ragu apakah akan meninggalkan profesi sekarang atau tidak. Dari hasil wawancara diperoleh informasi tambahan bahwa keraguan mereka dikarenakan adanya pilihan jabatan sebagai pejabat struktural di rumah sakit tanpa meninggalkan profesi tenaga medis secara total, dan faktor usia yang memang sudah memasuki masa pensiun, namun telah diperpanjang karena minimnya tenaga medis penggantinya.

Hasil penelitian menunjukkan bahwa responden tidak ada yang menyatakan akan pindah atau keluar dari RSUD dr. Soedirman. Namun $18 \%$ dari responden atau sebanyak enam tenaga medis yang ragu-ragu apakah akan berpindah atau keluar dari RSUD dr. Soedirman. Empat berstatus Pegawai Tidak Tetap, sehingga wajar apabila mereka masih memiliki kebebasan untuk memperpanjang kontrak atau tidak.
Dari olah hasil wawancara diperoleh informasi tambahan bahwa keputusan ragu-ragu untuk pindah lebih disebabkan pilihan alternatif untuk pindah yang selalu ada, namun juga tidak memilik kepastian perolehan yang lebih baik dari hasil sekarang. Hal ini menyebabkan mereka ragu untuk menjawab tidak, dengan harapan tetap bekerja di RSUD dr. Soedirman, namun masih berharap perbaikan status PNS atau perolehan kompensasi sehingga pendapatan mereka setara dengan tenaga medis PNS. Hal ini menunjukkan faktor terhadap pendapatan, jasa pelayanan, maupun kondisi lingkungan masih dapat diterima oleh tenaga medis

\section{SIMPULAN}

Terdapat disparitas yang cukup mencolok antar jenis tenaga medis dalam hal besaran jasa pelayanan yang diterima, tanpa ada mekanisme pemberian kompensasi lain diluar hal tersebut. Hal ini menyebabkan sebagian besar responden memilih tingkat kepuasan pada level sedang. Lingkungan kerja digedung baru cukup baik, nyaman, dan memiliki daya dukung untuk melaksanakan tugas. Sebagian besar responden menyatakan kondisi lingkungan kerja masuk kategori bagus. Namun untuk ketersediaan peralatan kerja yang masih terbatas, menyebabkan terdapat beberapa responden kurang termotivasi untuk meningkatkan kinerja.

Pendapatan, Insentif, dan Lingkungan Kerja memiliki kontribusi besar bagi tenaga medis dalam memberikan penilaian atas kepuasan dirinya terhadap apa yang diperolehnya dari pekerjaan dan motivasi untuk meningkatkan kinerja.

\section{DAFTAR PUSTAKA}

1. Hamzah B Uno, 2006, Teori Motivasi dan Pengukurannya, edisi 1, cetakan 10, PT Bumi Aksara, Jakarta

2. Gomes, Faustino Cardoso, 2003, Manajemen Sumber Daya Manusia Penerbit Andi, Yogyakarta.

3. Gomes, Faustino Cardoso, 2006, Manajemen Sumber Daya Manusia, edisi 2 Cetakan 1, Andi Offset, Yogyakarta.

4. Martoyo, Susilo, S.E. 2007. Manajemen Sumber Daya Manusia, Yogyakarta, BPFE- Yogyakarta. 
5. Bestari Tim Mitra. 2005. Manajemen Sumber Daya Manusia, Yogyakarta, UPFE-UMY

6. Robert L. Mathis \& John H. Jackson, 2006. Human Resources Management Edisi sepuluh, Penerbit Salemba Empat

7. Alex. S. Nitisemito, 2002, ManajemenPersonalia. EdisiRevisi, PenerbitGhalia Indonesia.

8. Robbins, P. Stephen. (2002). Perilaku Organisasi. Jakarta: Prenhalindo 